\title{
INTERNATIONAL TOURISM AS A NEOLIBERAL PRACTICE OF CHINESE INFLUENCE IN THE WESTERN BALKANS
}

\section{МІЖНАРОДНИЙ ТУРИЗМ ЯК НЕОЛІБЕРАЛЬНА ПРАКТИКА КИТАЙСЬКОГО ВПЛИВУ НА ЗАХІДНИХ БАЛКАНАХ}

\section{МЕЖДУНАРОДНЫЙ ТУРИЗМ КАК НЕОЛИБЕРАЛЬНАЯ ПРАКТИКА КИТАЙСКОГО ВЛИЯНИЯ НА ЗАПАДНЫХ БАЛКАНАХ}

\section{Parfinenko A.}

Ph.D (History), Assoc. Prof., Head of the Department of Travel Business and Regional Studies of the V. N. Karazin Kharkiv National University. E-mail: parfinenko@karazin.ua

\section{Парфіненко А.}

кандидат історичних наук, доцент, завідувач кафедри туристичного бізнесу та країнознавства Харківського національного університету імені В. Н. Каразіна. E-mail: parfinenko@karazin.ua

\section{Парфиненко А.}

кандидат исторических наук, доцент, заведующий кафедрой туристического бизнеса и страноведения Харьковского национального университета имени В. Н. Каразина. E-mail: parfinenko@karazin.ua

Abstract. The article reveals China's geostrategic interests in the Western Balkans. The paper highlights the main directions of Beijing's political and economic cooperation with the countries of the region, the impact of these processes on the foreign policy orientations of the Balkan countries. The focus is on assessing the international political potential of Chinese outbound tourism as a tool for neoliberal influence on the host destinations of the Western Balkans.

The work consists of three interrelated parts. The first part, within the neoliberal paradigm, reveals the understanding of tourism as a factor of international political interaction and the establishment of "complex interdependence". For China, which generates the largest outbound tourist flow, these human communications provide the possibility of indirect influence on host destinations through the created economic dependence and the approval of "official tourist destinations."

The second part of the study highlights the Chinese approach to the Western Balkans. It is motivated by the implementation of a large-scale project of the New Silk Road "Belt and Road Initiative", designed to create a cross-border transport and logistics network to accelerate the delivery of Chinese goods to European markets. In the context of this project, the countries of the Western Balkans have become a geographical "entry point" for both land and sea corridors of the new Silk Road, which connect the markets of Europe and Asia.

The third part of the publication shows that China's international political and investment activity in the Western Balkans is based on a network of transnational social ties created under the auspices of the state. An appropriate place among them is given to tourist flows from China, whose communication strategies influence emotional and commercial involvement, as well as a positive perception of China in the region. It has been concluded that the intensification of tourist contacts and the related liberalization of mobility regimes serve as an important factor in strengthening the complex asymmetric interdependence of the Balkans with China. In the long term, this will strengthen Beijing's position in Europe, especially in the context of global competition with the United States.

Key words: Western Balkans. China. Foreign policy. Belt and Road Initiative. International tourism. Tourist flows. 
Анотація. Стаття розкриває геостратегічні інтереси Китаю в регіоні Західних Балкан. Висвітлено основні напрямки політико-економічної взаємодії Пекіну з краӥнами регіону, вплив циих процесів на зовнішньополітичні орієнтири балканських країн. В центрі уваги - оцінка міжнародно-політичного потенціалу китайського виїзного туризму як інструменту неоліберального впливу на приймаючі дестинащії Західних Балкан.

Робота складається із трьох взаємопов'язаних частин. У першій частині у межах неоліберальної парадигми розкрито розуміння туризму як чинника міжнародно-політичної взаємодії та встановлення «комплексної взаємозалежності». Для Китаю, який генерує найбільший за обсягом виїзний туристичний потік, ия людські комунікації відкривають можливість опосередкованого впливу на приймаючі дестинації через створювану економічну залежність та затвердження «офіційних туристичних напрямків».

У другій частині дослідження висвітлено китайський підхід до Західних Балкан. Він зумовлений реалізацією масштабного проекту Нового шовкового шляху «Один пояс, один илях», покликанного створити транскордонну транспортно-логістичну мережу для прискорення доставки китайських товарів на ринки Європи. В контексті даного проекту крайни Західних Балкан перетворилися на географічну «точку» входу як для суходільного, так і для морського коридорів нового Шовкового шляху, які сполучають ринки Європи та Aзіï.

У третій частині публікащії показано, щуо міжнародно-політична та інвестииійна активність Китаю на Західних Балканах спирається на створювану під егідою держави мережу транснаціональних сочіальних зв'язків. Належне місие серед них відводиться туристичним потокам з Китаю, комунікативні стратегї яких впливають на емочійну та комериійну залученість, а також позитивне сприйняття Китаю в регіоні. Робиться висновок, щуо інтенсифікація туристичних контактів та пов'язана із цим лібералізація режимів мобільності виступають важливим чинником посилення комплексної асиметричної взаємозалежсності Балкан від Китаю. В довгостроковій перспективі ие посилюватиме позииії Пекіну в Свропі, особливо в контексті глобальної конкуренції зі США.

Key words: Західні Балкани. Китай. Зовнішня політика. Один пояс, один шлях. Міжнародний туризм. Туристичні потоки.

Аннотация. Статья раскрывает геостратегические интересы Китая в регионе Западных Балкан. Освещены основные направления политико-экономического взаимодействия Пекина со странами региона, влияние этих процессов на внешнеполитические ориентиры балканских стран. B центре внимания - оценка международно-политического потенциала китайского выездного туризма как инструмента неолиберального влияния на принимающие дестинации Западных Балкан.

Работа состоит из трех взаимосвязанных частей. $B$ первой части в рамках неолиберальной парадигмы раскрыто понимание туризма как фактора международнополитического взаимодействия и установления «комплексной взаимозависимости». Для Китая, который генерирует наибольший по объему выездной туристический поток, эти человеческие коммуникации открывают возможность опосредованного влияния на принимающие дестинации через создаваемую экономическую зависимость и утверждение «официальных туристических направлений».

Во второй части исследования отражен китайский подход к Западным Балканам. Он обусловлен реализачией масштабного проекта Нового шелкового пути «Один пояс, один путь», призванного создать трансграничную транспортно-логистическую сеть для ускорения доставки китайских товаров на рынки Европь. В контексте данного проекта страны Западных Балкан превратились в географическую «точку» входа как для сухопутного, так и для морского коридоров нового Шелкового пути, которые соединяют рынки Европьы и Азии.

В третьей части публикации показано, что международно-политическая и инвестиционная активность Китая на Западных Балканах опирается на создаваемую под 
эгидой государства сеть транснациинальных социальных связей. Существенная роль среди них отводится туристическим потокам из Китая, коммуникативные стратегии которых влияют на эмоциональную и коммерческую вовлеченность, а также позитивное восприятие Китая в регионе. Делается вывод, что интенсификация туристических контактов и связанная с этим либерализация режимов мобильности выступают важным фактором усиления комплексной асимметричной взаимозависимости Балкан от Китая. В долгосрочной перспективе это усилит позиции Пекина в Европе, особенно в контексте глобальной конкуренции со США.

Ключевые слова: Западные Балканыл. Китай. Внешняя политика. Один пояс, один путь. Международный туризм. Туристические потоки.

Research problem setting. The formation of a multipolar model of the political organization of the world is accompanied by the redistribution of power in international relations, a change in the role of major countries in world politics and the emergence of new centers of power with growing economic influence and political subjectivity. China has become an important center of the new world order. As Beijing's economic potential strengthens, its status in resolving international issues is rising, and its geopolitical ambitions, projected in various regions of the world, are increasing. The Western Balkans (WB) became one of such regions. From China's point of view, the region is part of Central and Eastern Europe (CEE), whose importance for China's foreign economic policy has significantly grown in recent years due to the implementation of the global New Silk Road project, now known as the Belt and Road Initiative (BRI).

The leading direction of China's policy towards the CEE countries has been the «16+1»initiative, which has been known as «17+1» since Greece joined in 2019. This multilateral format of cooperation is an important tool for implementing the BRI strategy, which expands China's geopolitical influence in most of Europe's post-socialist countries. Considering the Balkan countries as a «gateway» to the EU market, Beijing is increasing its investments, lending to infrastructure projects, expanding trading activities, and so on.

Today, China's presence in the Balkans has not only foreign economic forms, but also entirely human dimensions. The matter is that followed by the business activity, countries of the Western Balkans began to be actively visited by tourists from China, which was even a reason for accusations of espionage [24]. As is well known, China retains the first place in the world in terms of both the volume of outbound tourist flow and the cost of tourist travel. These human communications primarily exert a powerful economic influence on the host destinations used by Beijing, including for indirect political influence. This has been demonstrated in the case of the United States, South Korea, Taiwan, the Philippines, and other countries with which China has formed a high level of bilateral relations and heavy traffic of spatial mobility. In view of this, the study of the political and economic aspects of the impact of Chinese tourism on the determination of the main directions of China's interaction with the countries of the Western Balkans deserves comprehensive attention.

The objective of the article is to clarify the international political potential of the impact of Chinese tourism on the Western Balkans as a neoliberal practice of establishing transnational cooperation and forming a «complex interdependence». The focus is on the analysis of international political processes that have led to the intensification of Chinese tourism in the region and the consequences of the impact of transnational tourist flows on economic, cultural and foreign policy processes in the host region.

Analysis of recent research and publications. Various aspects of China's influence on the $\mathrm{CEE}$ and WB countries have been reflected primarily in the works of scientists from these countries, in the analytical materials of research centers and foundations, as well as in the works of scientists from Ukraine and Russia. Among the numerous publications of recent years are the works of K. Entina, J. Garlick, M. Grabowski, V. Kiktenko, B. Kowalski, T. Matura, D. Pavlićević, P. Tonchev, A. Vangeli and others. Despite the sufficiently full disclosure of the theme, tourist interaction remained almost out of the authors' attention. The positive exceptions are P. Tonchev's 
publication [22], published by the German Friedrich Ebert Political Foundation, which reveals the role of China's soft power in Southern Europe, as well as the economic study of Montenegrin and Slovenian scholars «Chinese tourists in the Western Balkans: facts and forecast»[19]. Against this background, the political component of Chinese tourism in the Balkans remains virtually undisclosed.

\section{Tourism as a factor of international political influence}

The modern neoliberal tradition (R. Keohane, J. Nye) considers social institutions, socioeconomic groups and processes, which include travel and tourism, as full participants in international relations, «sovereignty-free actors»(J. Rosenau). Accordingly, their political potential, ability to influence the dynamics of social relations through the established network of transnational ties and communities is recognized. One of the areas that well illustrates these processes is the field of international tourism.

In international relations, the theory of neoliberalism also provides for the recognition of the growing openness of borders, which arises from the increased mobility of ideas, capital, information, people, goods and services. National, cultural and social borders are becoming increasingly transparent. With the spread of information and communication technologies, communities, individuals and organizations from different countries are becoming increasingly delocalized and connected by cross-border communication networks.

One of the first who drew attention to tourism as a full-fledged actor in world politics was the famous American researcher of world political processes J. Rosenau. As early as the 1960s, considering the radical changes in the system of international relations that took place under the pressure of globalization processes, he noted the expansion of the number of participants in international relations at the expense of non-governmental and private entities. Later in the article 'The Tourist and the Terrorist: Two Extremes on a Transnational Continuum', published in 1979, J. Rosenau noted in metaphorical form that the consequence of changes in the system of international relations is the formation of the so-called «Transnational Continuum», symbolic characters of which are a tourist and a terrorist [Rosenau, 1979: 220]. This statement has long been used as quotations and has not lost its relevance to the present time. And the global, ever-increasing volume of tourist flows provides even more grounds for the inclusion of tourism in the sphere of international political communication, its use for important economic and political transformations.

Modern international tourism is a complex transnational entity that is developing worldwide, it is deeply integrated into the global economic and trade relations that form the "Complex interdependence» (R. Keohane, J. Nye). Therefore, the structure of global tourist flows has not only its own economic logic, but also its own political tradition, political ties and deep-rooted political implications. Mass travel practices, which are actively expanding their network through the spread of modern means of communication, form a kind of transnational social space in which the tourist is always an actor, as he performs many social actions related to interaction with another environment.

Global tourist flows have become a planetary phenomenon that crosses the boundaries of a purely economic sphere. The spatial structure of world tourist flows today reflects the main vectors of international political interaction. The number of international tourist arrivals has been growing rapidly in the world since the second half of XX century. From 25 million international tourists in 1950 to almost 1.5 billion arrivals in 2019. Correspondingly cash inflows from tourism have increased, which today reach $\$ 1.7$ trillion or almost $\$ 5$ billion daily [International Tourism Highlights, 2019: 8]. The tourism industry currently accounts for 10.4\% of world GDP and 10\% of total employment (319 million jobs) [Travel \& Tourism: Economic impact, 2019: 1].

The rapid development of Chinese outbound tourism has transformed it into one of the drivers of the international tourism market and the world economy as a whole. About $12 \%$ of China's 1.4 billion population travel abroad. In 2018, this figure reached almost 150 million people, which is $10 \%$ of world tourism flow (Figure 1). In terms of travel expenses, China ranks first in the world. In 2018, Chinese tourists spent $\$ 277.3$ billion abroad, while the expenses of American foreign tourists amounted to $\$ 144.2$ billion. (Figure 2) [International Tourism Highlights, 2019: 15]. 
Dynamics of outbound tourist flow from China, 2000-2019

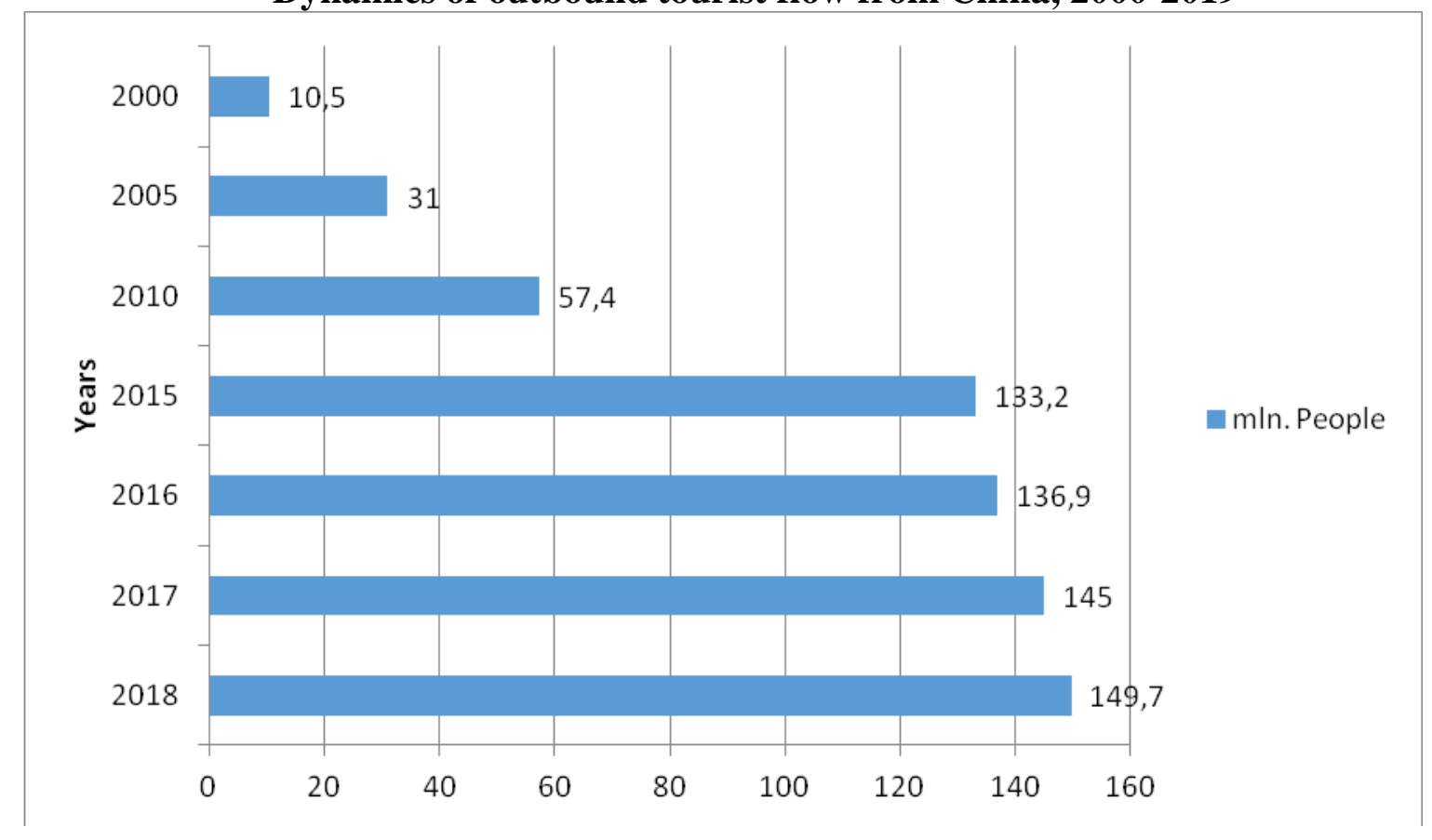

Source:[Smith, 2019]

Top 10 countries by international tourism spending, 2018

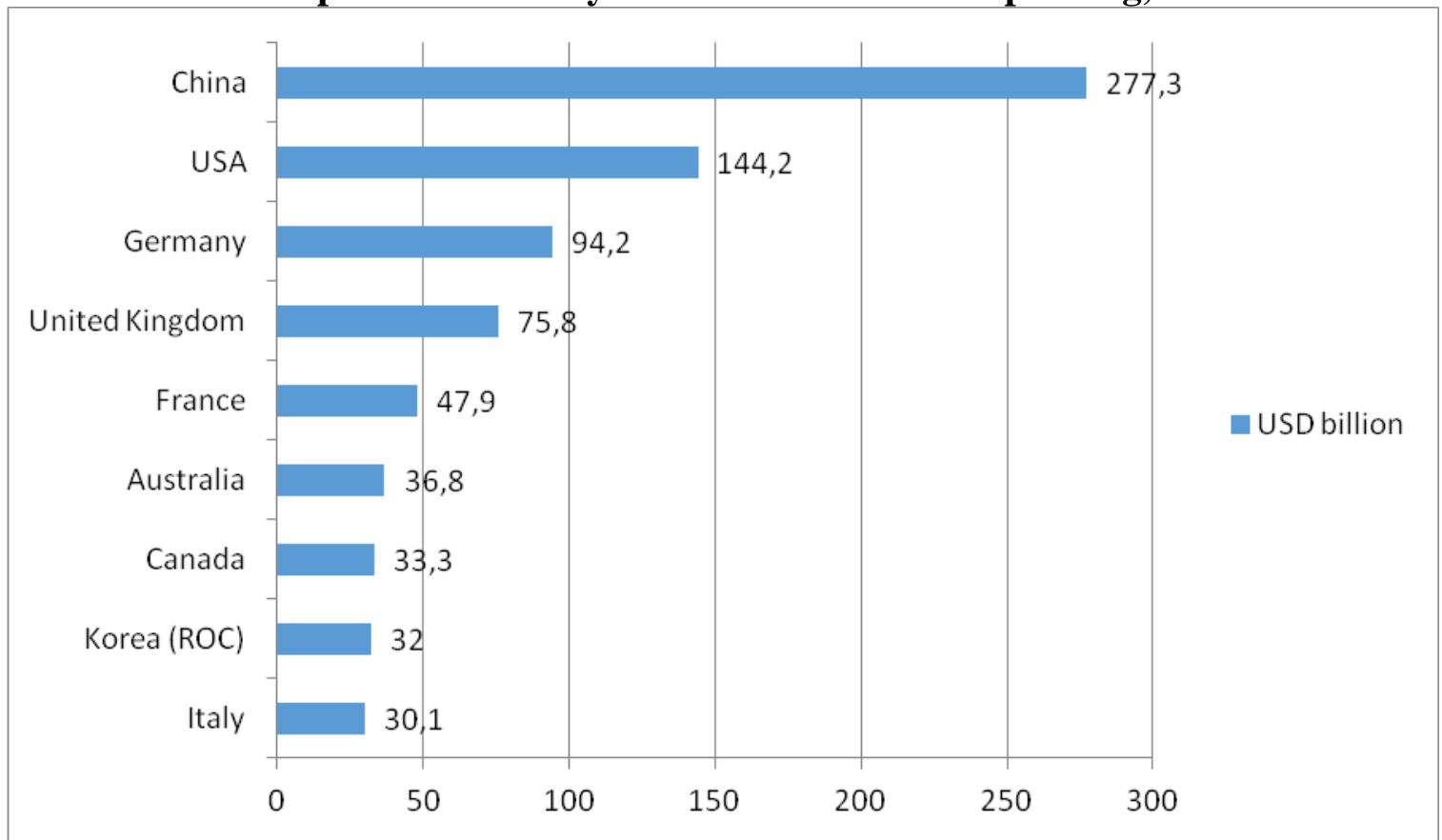

Source: author's development based on materials [International Tourism Highlights, 2019:15]

Tourism is usually identified as an influencing factor of so-called «soft power», considered in the paradigm of «public diplomacy» due to its ability to establish dialogue at a low political level. But given that Chinese outbound tourism has been used repeatedly as a tool of coercion, it can be defined as soft power with tools of hard pressure. This is achieved by creating an economic 
dependence of the host tourist destination on the foreign exchange earnings of Chinese tourists. For example, China's response to the deployment of the US missile defense system THAAD in South Korea in 2017 was a boycott of South Korean companies and restrictions on tourist contacts with Seoul. China launched an aggressive, unofficial campaign aimed at reducing Chinese travelers' group travel to the neighboring country. According to South Korea, as a result of the boycott, which lasted from January to September 2017, the tourist flow from China decreased by more than 4 million people and cost the country's tourism industry about $\$ 6.7$ billion [Lee Jeong-ho, 2018]. This has put enormous pressure on Seoul and demonstrated China's willingness to use tourist flows as a tool of foreign policy influence [Varaksina, 2018]. A similar situation occurred during the trade war between the United States and China, when Chinese tourist flow to the United States decreased, and The Foreign Policy, The Washington Post, The Diplomat, and other authoritative publications called Chinese tourists «Beijing's latest economic weapon»[Coca, 2018; Lynch, 2018; Panda, 2019].

It should be taken into consideration that Chinese tourists are willing to spend money in the host country, which has both direct and indirect economic impact. In addition to the cost of purchasing a tourist trip, the Chinese prefer package group tours, the service requires Chinesespeaking guides, guidebooks, special menus in restaurants, souvenirs, etc. Chinese travelers are actively engaged in shopping, which is also due to the peculiarities of Asian culture, which is characterized by a system of building relationships through gifts [Chzhan: 115-116]. Accordingly, the popularity of shopping malls abroad is often associated with the opportunity to shop for friends and family. In addition, tourists from China are actively interested in casinos, nature and cultural heritage, which makes them active consumers and welcome guests for many destinations around the world.

\section{Chinese approach to the Western Balkans}

From a historical point of view, the Western Balkans have always been at the epicenter of European policy and, unlike Russia or Turkey, have not been among China's geostrategic priorities. China's economic presence in the former Yugoslav republics began to grow rapidly in the early 2010s. As it has been indicated, this was connected with Beijing's implementation of the global BRI project, which involves the creation of a cross-border transport and logistics network aimed at accelerating the delivery of Chinese goods to Western Europe.In the context of this project, the CEE countries have become a geographical «entry point» for both the land and sea corridors of the new Silk Road, which link the markets of Europe and Asia.

The land route originates in Western China, passes through Russia or Central Asia, from where the cargo enters CEE and further into Western Europe. In this way, China gains a strategic advantage from diversifying part of its maritime supplies by reducing the use of the Straits of Malacca. The commercial benefit of the land route is to reduce the delivery time of goods by half compared to maritime transport [Miheev, Shvyidko, 2016: 38].

No less important is the maritime route, which provides for the delivery of goods from China to the Balkans. Previously, $80 \%$ of Chinese exports went to European markets through the Suez Canal and beyond, encircling the whole of Europe to the ports of the northwest coast (Antwerp, Hamburg, Rotterdam). With the BRI project, Chinese exports will now go directly through the Suez Canal to the Greek port of Piraeus, and then by rail through the Western Balkans to Hungary and Western Europe. In this way, the total time to cover the distance is reduced from 30 to 20 days [Entina, 2016: 58].

The «road map» of the BRI project envisages the development not only of transport and logistics, but also of political cooperation, which deepens the interdependence with the member states of the Chinese initiative, especially the CEE countries. It is based on five pillars: infrastructure development, policy coordination, trade facilitation, financial integration, and spatial mobility of people between China and the countries covered by the BRI [National Development and 
Reform Commission of the People's Republic of China, 2015]. The same goals are pursued by the $« 17+1 »$ platform through various initiatives and priority areas.

The «17+1» Beijing-initiated framework platform for multilateral cooperation (17 European countries on the one hand and Beijing on the other), has deepened economic ties between China and the region and given the Balkans a key role in the BRI project. The new format brings together quite different countries in many respects, which have a common socialist past and common European integration aspirations. In particular, the three Baltic states, the Visegrad Four countries, the WB countries and the former Yugoslavia, as well as Bulgaria, Romania and Greece. Among the priorities for the consolidation of this colorful region, China hasproposed the idea of creating crossborder transport corridors and developing economic cooperation. In 2007-2017 alone, China's investment in the region reached $\$ 12$ billion. Moreover, a third of this amount was invested in Serbia, which has become a key partner of the Chinese in the WB [Gabrielyan, 2019].

The beginning of China's «expansion» in the region was the Greek port of Piraeus, which after investing more than 1 billion went into a long-term concession. The ports of Thessaloniki and the Montenegrin city of Bar will also be strongholds for China's entry into the region. With the financial support of Beijing, the construction has begun on a high-speed railway between Serbia and Hungary, the Bar-Bolyare highway (connecting Montenegro and Serbia); highways between Albania and Montenegro, highways in Albania, Bosnia and Herzegovina $(\mathrm{BiH})$, and northern Macedonia. In 2016, «China Everbright» received a concession to Tirana International Airport [Mardell, 2020].

Energy projects have also become an important area of Beijing's investment policy in the region as well as investments in mining and heavy industry. Against this background, the Serbian metallurgical giant «ZelezaraSmederevo»particularly stands out, which, on the verge of bankruptcy, was bought in 2014 by the Chinese group «HebeiIron\&Steel» for 46 million euros [Gabrielyan, 2019]. In order to support business projects in the Balkans, the State Bank of China «ExImBank» has established a special investment fund. Among the priority countries receiving financial support are future potential EU members: Montenegro, Serbia, Northern Macedonia [Garaeva, 2018], which may indicate a desire to use the acquired assets in the medium term for further trade expansion in the Union.

Against the background of investment and political activity of global players in the Balkans (EU, USA, Russia, Turkey), increasing China's presence in the region has become a new «hot» issue for politicians, experts and scholars. Of concern to all: what are Beijing's real intentions in a region that has traditionally been a field of the clash of interests between Russia and the West? It is known that global Chinese initiatives have repeatedly been described as a new form of «neocolonialism» [Blanchard, 2018], the «Great Game of China», thatis building the way to a «new empire» [Clover, Hornby, 2015]. And the practice of lending without any political «conventions and commitments» has been criticized in the Western expert community as potentially «destroying the EU's reform-oriented approach» [Mardell, 2020]. D. Pavlićević rightly focuses on that such «negative perceptions» of China's relations with CEE countries have been established as an influential evaluation paradigm [Pavlićević, 2019: 252]. Indicative in this sense is the Munich Security Conference 2019, during which in one of the public reports, Chinese investment policy was described as «debt-trap diplomacy». It was alleged that Montenegro owed China the equivalent of $80 \%$ of its GDP. These data indicate that China accounts for $20 \%$ of Macedonia's external debt, for $\mathrm{BiH}$ this figure is 14\%, and for Serbia - 12\% [Gabrielyan, 2019].

The concern of the "collective» West with the presence of international actors and the aggravation of security issues in the post-Yugoslav space influenced the EU's decision to accelerate further integration with the region. Thus, in early 2018, the European Commission (EC) presented a new strategy for the Western Balkans, in which ensuring the accession of the region to the EU was called a «geostrategic investment» in a united Europe [European Commission, 2018].

A year later, in March 2019, the EC outlined the strategic prospects for cooperation with China [European Commission, 2019] in the context of its growing importance as a world power and pointed out the risks associated with China's participation in the Balkans. While acknowledging the 
overall positive impact of China's business and investment activity on the region, the EC expressed concern about the non-transparent nature of the partnership with Beijing. These investments, the strategy noted, often «neglect socio-economic and financial sustainability and EU public procurement rules» and can lead to «high levels of debt and transfer of control over strategic assets and resources» [European Commission, 2019: 4]. The strategic priorities set by the EC for cooperation with China directly affect China's partnership practices with the CEE countries. Among them: «address the distortive effects» of foreign state ownership and public funding of projects, strengthening security in relation to digital infrastructure $(5 \mathrm{G})$, increased reviewing of investors in critical infrastructure [European Commission, 2019: 10-11].

Against the background of the obvious concerns of EU political circles about the spread of China's economic and geopolitical influence in the CEE countries, in particular in the Balkans, it is worth asking about the degree of China's influence in the region. It is clear that the politicization of China's presence in the Balkans has also reflected the general escalation of geopolitical rivalry between key actors in international relations. At the same time, the «17+1» initiative, as well as the $\mathrm{BRI}$, is an integration project in the Eurasian political space that competes with the EU integration project, which seeks to protect business interests of large European companies. This is, in particular, directly indicated by the EC, which defines China as a «systemic rival» that «promotes alternative models of governance» [European Commission, 2019: 1].

However, China's desire to increase its influence in the Balkans should hardly be considered as an alternative to European integration. On the contrary, Beijing is interested in including the countries of the region in the EU, which will create additional opportunities for Chinese companies to enter EU markets. Another thing is that further deepening of cooperation between communist China and the countries of the region carries the danger of Beijing gaining leverage over the autocratic political regimes in the Balkans in order to gain power in the EU. In this sense, China's global expansion is perceived as an existential threat to the EU's liberal democratic values, and Chinese projects as a «conductor of China's political and regulatory influence» [Makocki, Nechev, 2017], which often leads to «erosion of regional order in the EU».

The Covid-19 pandemic has exacerbated global antagonism. Against this background, «mask diplomacy»has allowed China to increase its ideological influence in the WB and to some extent damaged the legitimacy of the global leadership of the EU and the United States. Thus, the press has already suggested that due to Beijing's successful «blitz» of humanitarian aid to countries struggling with outbreaks, China is taking on a role traditionally dominated by the West [Myers, Rubin, 2020]. A clear illustration of this thesis is the statement of the President of Serbia, Aleksandar Vucic, who during a television speech about the declaration of a state of emergency in the country stated that «European solidarity does not exist", that it was a «fairy tale on paper». «I believe,» the appeal said, «in my brother and friend Xi Jinping, and I believe in Chinese help» [Popović S., 2020].

Thus, the interaction between Beijing and the WB countries takes place not only in the economic sphere, but also actively uses diplomatic channels to achieve ideological influence. In this sense, the intensification of social contacts through the development of tourism practices of Chinese tourists in the Balkans has enabled to create an important communication network that simplifies the processes of joint production of symbolic images and meanings and improves China's perception in the region.

\section{The Western Balkans - a «hot spot» for Chinese tourism}

the Chinese tourist hot spot

As part of the BRI project, as well as the «17+1» cooperation initiative, China has significantly increased its presence in the WB region. This is also applied to the implementation of projects for the development of spatial mobility, which include: political interaction, business contacts, academic exchanges, tourist visits, etc. 
The growing flow of Chinese tourists is a clear example of the coherence of Beijing's foreign policy positions with the countries of the region. Thus, back in May 2014, within the framework of the «16+1» initiative, the Coordination Center of the China Tourism Association with the CEE countries was established in Budapest [Bofulin and Raspor et al., 2016], due to which direct flights from China to the region were launched, visa regime was liberalized, and the number of Chinese tourists has increased significantly. The considerable role of spatial mobility in Beijing's further penetration into Europe is evidenced by the annual High-Level Tourism Forum, which gathers Chinese and CEE tourism ministers and is one of the important events within the $« 17+1 »$ initiative [Tourism ministers, 2019].

Serbia is a strategic partner and Beijing's «entry» tourist destination in the WB. This has been influenced by both the experience of bilateral co-operation during the socialist Yugoslavia and Belgrade's growing political influence in the region. The development of Sino-Serbian diplomatic relations is also based on the traditional political support of the national interests of the states in the international arena. Beijing has always supported Belgrade on the Kosovo issue, and Serbia has supported the «One-China policy». The symbol of Sino-Serbian friendship in Belgrade has become a bridge built under a concessional loan of 170 million euros provided by China, which has connected both banks of the Danube [Entina, 2016: 62]. Accordingly, the «air gate» for Chinese tourists and workers in the Western Balkans was Belgrade, with which a direct air connection was established. Since 2015, Serbia has become a «hot spot» for Chinese tourism.

It is obvious that one of the factors of Serbia's tourist attractiveness has not only been the tourist resources of the Western Balkans, but also Beijing's policy of «official tourist destinations» [Zaklyazminskaya, 2018], which provides visa preferences for group tourists and allows to control and direct flows in the desired direction. Chinese President Xi Qinping's state visit in 2016 did not only raise the state of Sino-Serbian relations to a «comprehensive strategic partnership» [Kitay and Serbia, 2016], but also launched a visa-free regime between Serbia and China in 2017. The liberalization of the mobility regime has affected the growth and, at the same time, the politicization of the tourist flow from China. In particular, especially critical assessments were made about the introduction of joint Serbian-Chinese police patrols in Belgrade, Novi Sad and other cities, officially designed to consider the safetyissues of visitors from China.Against this background, the launch of the fifth generation (5G) mobile communication station by Serbia in 2019, provided by the Chinese company Huawei, which was criticized for espionage, became no less resonant. To maintain security in the Serbian capital, about 1,000 face recognition cameras were purchased, which are located throughout Belgrade as part of the Chinese project «Safe City» [Kumaŭskie i serbskie policejskie, 2019].

The introduction of visa-free travel with China has enabled Belgrade to significantly increase its tourist flow and monetary proceeds from tourism. If in 2016 Serbia was visited by 43 thousand Chinese tourists, in 2019 this figure reached 145 thousand people (Figure 3), not including businessmen and employees of Chinese companies. Monetary proceedsfrom tourism reached $\$ 2.2$ billion. On average, tourists spend 2,3 days in the country, which is a very positive result for the WB [Garaeva, 2018]. At the same time, such activity of Chinese tourists has become a reason for suspicion of gathering intelligence [Balkan Countries Spy Potential in Chinese Tourism, 2018]. 
Dynamics of growth of inbound tourist flow from China to Serbia

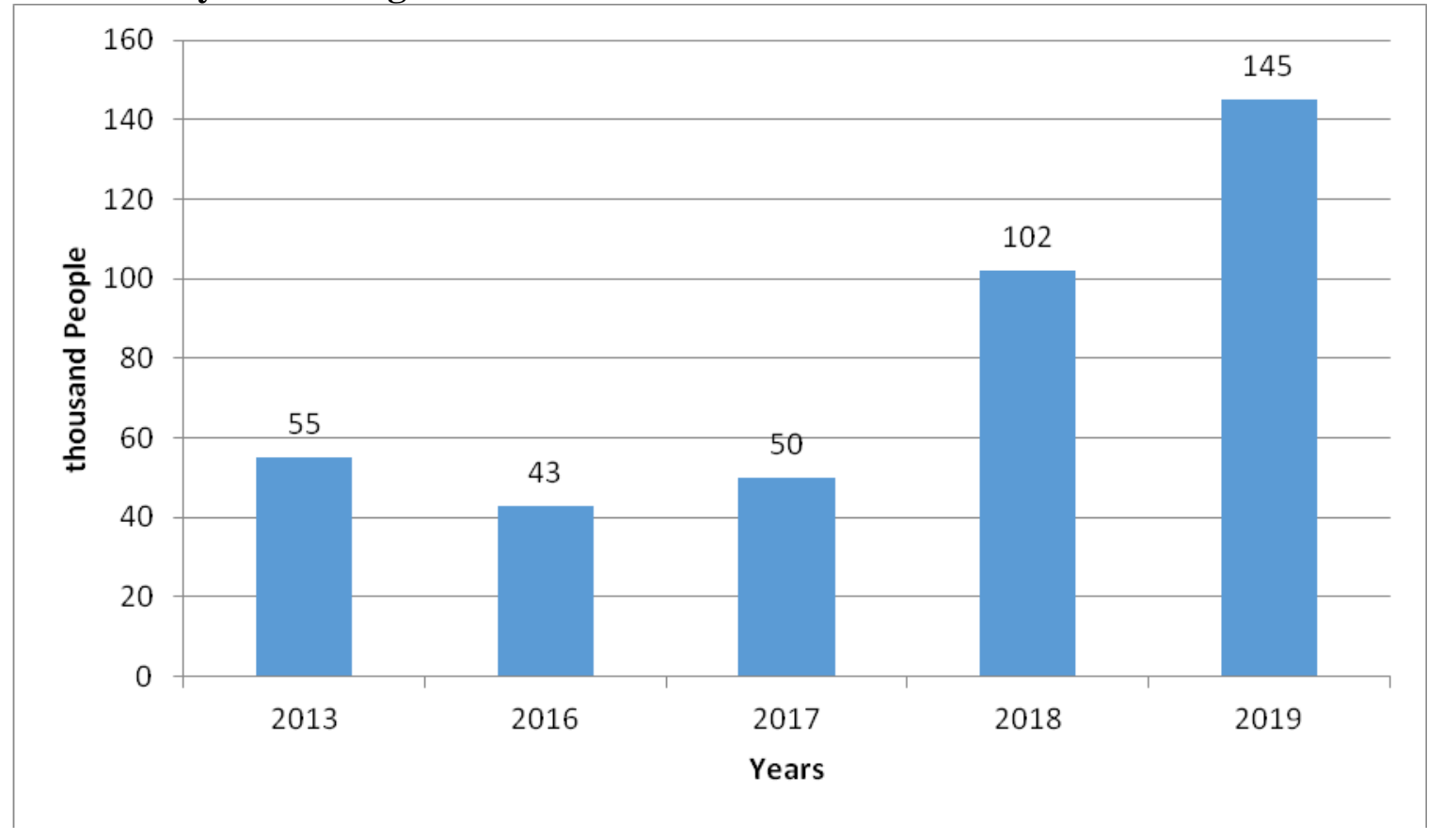

The communicative component of Chinese tourism in the Balkans is aimed at ensuring mutual understanding and integration of social actors through the production of common cultural and symbolic meanings. In particular, the «common» is the pain of the losses suffered by Chinese society together with the Yugoslavs in May 1999 as a result of an American air bomb hitting the Chinese embassy in Belgrade. The terrible tragedy is still «alive» in the minds of the Chinese people, and the image of the United States as an aggressor is deliberately produced through the appropriate memory policy. It is symbolic in this sense that today one of the largest Chinese cultural centers in Europe is being built on the site of the former embassy. And for many Chinese tourists, a stop at the memorial at the site of the tragedy is an indispensable part of a visit to the Balkans. It is here that they learn that one of the consequences of the NATO military campaign in Yugoslavia, which was also opposed by China, was the attack on «a symbol of China's sovereignty in the heart of the Balkans» [Ponniah, Marinkovic, 2019] and the death of three Chinese journalists. In this case, the projection of twenty-year-old events on the current state of US-China relations is quite obvious, which involuntarily affects relations between the United States and Serbia, and the general discourse around this forms the idea of the United States as an aggressive state.

Undoubtedly, the Covid-19 epidemic made its adjustments to further tourism interaction in the WB, but Serbia did not abandon pre-planned measures to attract Chinese tourists. Thus, back in September 2019, the Tourist Organization of Serbia signed a contract with the Chinese company «Alibaba»to promote the Balkan state on all platforms of the company and within the social boundaries of «WeChat»and «Weibo».It is noteworthy that the direct participant in marketing events was the President of Serbia Alexander Vucic, whose photo was placed on posters inviting the Chinese to visit Serbia [Stojanovic, 2020].

Serbia's example of introducing a visa-free regime with China in 2018 was followed by $\mathrm{BiH}$, and Albania, Croatia and Montenegro weakened conditionsfor entry, which enabled to make a comprehensive tourist offer. In this case, it is interesting to pay attention to its individual leitmotifs, which are aimed at creating a material and symbolic space within which an interpenetration of different cultures and the creation of a common experience take place. The «Ex-YuTour», a package tour for Chinese tourists [Ex-Yu-Tour, 2020], for which the Montenegrin company «FlyMontenegroTravel»received the Marco Polo Gold Award from the High-Level Tourism Forum, focuses on «Tito's Paths». Thus, the Josip Broz Tito Memorial Center in Belgrade is an 
integral part of the visit. The so-called «Walter effect» is also widely known in the Balkans. For Chinese tourists, the film «Walter Defends Sarajevo» (1972) became a cult hit for several decades. It was one of the few foreign films in Maoist China that was allowed to be watched. For the WB, this film is an important metanarrative that tells an important story between China and the Balkans and shapes Sino-Balkan relations in the coming years. In 2019, a museum of the legendary film was opened in $\mathrm{BiH}$, which presents wax figures of the characters. The film tells a story of the Yugoslav partisan Vladimir Perić, known by the pseudonym «Walter». The film was shown in more than 60 countries, and in China it was watched by more than 300 million people. The Chinese named their children and renamed the streets in honor of the main characters, as well as created a special brand of beer «Walter»with the image of the main actor Velimir Živojinović on the label [Hui, 2019].

In general, for Chinese travelers, the so-called «red tourism», dedicated to the objects of the communist past, is a significant market segment both in China and in the countries of the former socialist camp. Other popular Chinese tourist attractions on the «Ex-YuTour» include a concrete arch bridge over the Tara River in northern Montenegro. At the time of its completionin 1940, it was the largest concrete arch bridge in Europe, $172 \mathrm{~m}$ above sea level. But it is also interesting for the Chinese because it has become one of the central plots of the Yugoslav military drama «Bridge»(another name «In the Footsteps of the Tiger», 1969). The events of the film tell about the heroic actions of the Yugoslav sabotage group of Major «Tiger» (Velimir Živojinović), who was given the task to blow up the bridge and stop the Nazi offensive.

The rich communist past attracts the attention of many generations of Chinese tourists. P. Tonchev points out that similarly, a whole generation of Chinese grew up watching Albanian films until the late 1970s and is now a very likely segment of tourist flows to Albania [Tonchev, 2020]. An important platform for expanding China's cooperation with this country will be the investment project of the financial group «China Everbright», which acquired concession rights to Tirana International Airportin 2016.

Nevertheless, it's not just the rich communist legacy of the WB that is of Chinese tourist interest. Chinese tourists are actively interested in the rich historical and natural heritage, folk traditions, gastronomy and others. Croatia, which is the leading Chinese tourism destination in the region, is a vivid illustration. In 2018, Croatia attracted more than 234 thousand Chinese tourists with almost 345.3 overnight stays. These figures show a $46 \%$ increase over last year. And the growth forecast for 2019 was at the level of 25-30\% [Parulis-Cook, 2020]. This destination has also become widely known among Chinese tourists thanks to the cinema. If for the elderly and middleaged «hits» were the films of the Cultural Revolution in China, for young tourists such a «magnet»was the series «Game of Thrones», which was filmed on the coast from Dubrovnik to Split.

At the same time, Croatia's tourist popularity with Chinese tourists also has a political component, as flows follow the government's political activity, thus deepening the «comprehensive interdependence» with the little-known region. In particular, the press has already expressed the opinion that the destination belongs to the«official tourist destinations» [Parulis-Cook, 2020]. This is indirectly evidenced by summits. Thus, during the VIII summit in the format of «17+1», which first took place in 2019 in Zagreb, Chinese Premier Li Keqiang stated that both countries have entered a «diamond period of relations» [Croatia and China Entering Diamond Period", 2019]. China is working on major infrastructure projects in Croatia -the construction of the Pelesat Bridge, which is to connect the peninsula with the mainland of Croatia. It should be noted that this is the first project within the EU implemented by a Chinese company [Hirkić, 2020]. It has to be assumed that the expansion of the economic presence dictates to Beijing the need to interact with the general public. It is thoughtthat it is in this context should be taken the announcement of 2019 as the SinoCroatian Year of Culture and Tourism, which was launched for the first time among the CEE countries with Croatia. The high level of bilateral relations and tourist contacts is evidenced by the practice of joint police patrols in Croatian cities, which takes place together with Chinese police for the safety of Chinese tourists [Hirkić, 2020]. 
The formation of China's interdependence with the WB countries is influenced by other communication practices: business communication, labor migration, cultural and academic exchanges, and others. Thus, $\mathrm{P}$. Tonchev draws attention to the fact that friendship associations in all CEE countries are a common form of bilateral contacts. Chinese language training centers based on the Confucius Institutes have become widespread. Moreover, in different WB countries, language programs are offered to both civil servants (Northern Macedonia) and introduced into the educational process of primary and secondary schools (Serbia), which indicates the long-term nature of Chinese investment. Young people from the Balkan countries receive academic scholarships to study in China. Among them, the largest number in 2017 were Serbian students (446) [Tonchev, 2020: 10-11].

A. Vangeli points out the political aspects of the scientific cooperation of the CEE Analytical Centers with the relevant institutions of China (in the Western Balkans, the largest such centers exist in Serbia and $\mathrm{BiH}$ ). Frequent visits to $\mathrm{CEE}$ scholars have a tight agenda, including conferences, seminars, lectures, discussions and study tours. Thousands of political scientists, economists, and representatives of other sciences, who had the opportunity to visit the Celestial Empire, took part in these dialogical processes. These processes are «asymmetric» in nature. In the sense that «Chinese actors convene and manage interaction». These structures greatly influence the process of spreading powerful geoeconomic ideas about the economic greatness of China, which is depicted through trains and container vessels and mapping the routes of the New Silk Road [Vangeli, 2019].

Conclusions and prospects for further research.China's international political and investment activity in the WB is based on a state-sponsored network of transnational relations. A proper place among them is given to tourist flows from China, which are designed to act as a tool for the formation of a complex asymmetric interdependence of the Balkans with Beijing.

The analyzed practices of spatial mobility show that in the process of tourist consumption, which has a material and symbolic nature, new activity contexts, norms and expectations are formed, which affect the configuration of domestic and foreign policy of the Western Balkans. Take at least the dictated need to attract Chinese tourists to liberalize mobility regimes, the Serbian president's participation in the country's marketing campaign in China, involving Chinese police in joint patrols of Balkan cities to maintain the safety of Chinese tourists, intensifying the region's presence in Chinese virtual and communication networks. Together with the creation of a friendly infrastructure for Chinese tourists (cafes, restaurants, guides, guidebooks, attractions, etc.), all this creates an atmosphere of emotional and commercial involvement, which will affect further vectors of foreign economic policy in the region.

At the same time, the results of the study suggest that China is implementing the practice of cooperation not only with the political elites of the Balkan countries, but also interacts with the public. Unlike Russia, having no claims to the Euro-Atlantic orientation of the countries in the region, this creates a favorable political basis for further entry into EU markets as the Balkan countries integrate. In general, this strengthens China's position in Europe, especially in the context of global competition with the United States. Prospects for further research are to assess the impact of Covid-19 on the tourism sector of the WB, but also in the further disclosure of the mechanisms of international political action of tourism.

\section{References}

1. European Commission (2018) 'A credible enlargement perspective for and enhanced EU engagement with the Western Balkan', 6 February, <https://ec.europa.eu/commission/sites/betapolitical/files/communication-credible-enlargement-perspective-western-balkans_en.pdf $>$.

2. European Commission (2019) 'Joint communication to the European parliament, the European council and the council: EU-China, a strategic outlook', 12 March, $<$ https://ec.europa.eu/commission/sites/beta-political/files/communication-eu-china-a-strategicoutlook.pdf $>$. 
3. National Development and Reform Commission of the People's Republic of China (2015) 'Vision and Actions on Jointly Building Silk Road Economic Belt and 21st-Century Maritime Silk Road', <http://en.ndrc.gov.cn/newsrelease/201503/t20150330_669367.html>.

4. Blanchard, Jean-Marc F. (2018) 'Revisiting the Resurrected Debate About Chinese Neocolonialism', The Diplomat, 8 February, <https://thediplomat.com/2018/02/revisiting-theresurrected-debate-about-chinese-neocolonialism/>.

5. Bofulin M., Raspor, A., Stranjančević A., Bulatović I., Lacmanović D. (2016) 'Small Destinations In Large Tourism Market: The analysis of Western Balkan countries and the Chinese outbound tourism', International Scientific Journal 8: 130-143.

6. Clover C., Hornby L. (2015) 'China's Great Game: Road to a new empire', Financial Times, 12 October, <https://www.ft.com/content/6e098274-587a-11e5-a28b-50226830d644>

7. Coca N. (2018) 'Chinese Tourists Are Beijing's Newest Economic Weapon', Foreign Policy, 26 September, <https://foreignpolicy.com/2018/09/26/chinese-tourists-are-beijings-newesteconomic-weapon/>.

8. Hirkić M. (2020) China in the Balkans - Part 2: Croatia, Forum für Mittelost- und Südosteuropa, < < $\quad<t$ s://www.fomoso.org/en/mosopedia/background-knowledge/china-in-thebalkans-part-2-croatia/>.

9. Hui M. (2019) 'China loves this obscure 1972 Yugoslavian movie - and Sarajevo is cashing in', Quartz Media, 13 April, <https://qz.com/quartzy/1589664/chinas-love-for-old-yugoslav-warmovie-fuels-balkan-tourism-boom/>.

10. Lee Jeong-ho (2018) 'Seoul making Beijing a foreign policy priority by setting up bureau exclusively for China affairs', South China Morning Post, 22 December, <https://www.scmp.com/news/china/diplomacy/article/2179195/seoul-making-beijing-foreignpolicy-priority-setting-bureau>.

11. Lynch D. J. (2018) 'China has a big weapon that it hasn't used in the trade war yet: tourists', Washington Post, 30 October, <https://www.washingtonpost.com/business/economy/china-has-abig-weapon-that-it-hasnt-used-in-the-trade-war--yet-tourists/2018/10/29/a5645ae4-ccaf-11e8-a36085875bac0b1f_story.html?noredirect=on>.

12. Makocki M., Nechev Z. (2017) 'Balkan Corruption: The China Connection', Issue Alert 22, The European Union Institute for Security Studies, <https://www.iss.europa.eu/publications/detail/article/balkan-corruption-the-china-connection/>.

13. Mardell J. (2020) China's Economic Footprint in the Western Balkans, Bertelsmann Stiftung, $<$ https://www.bertelsmannstiftung.de/fileadmin/files/BSt/Publikationen/GrauePublikationen/asia-policy-brief-chinaseconomic-footprint-in-the-western-balkans-28c4d775834edcc469f4f737664f79f932d6f9a1.pdf>.

14. Stojanovic M. (2020) 'Serbian President Fronts Campaign to Lure Chinese Tourists', Balkan Insight, 15 May, https://balkaninsight.com/2020/05/15/serbian-president-fronts-campaign-to-lurechinese-tourists/.

15. Myers S. L., Rubin A. J. (2020) 'Its Coronavirus Cases Dwindling, China Turns Focus Outward', The New York Times, 18 March, <https://www.nytimes.com/2020/03/18/world/asia/coronavirus-china-aid.html>.

16. Panda A. (2019) 'China's US Travel Alert: Weaponizing Tourism Amid the Trade War?', The Diplomat, 05 June, <https://thediplomat.com/2019/06/chinas-us-travel-alert-weaponizingtourism-amid-the-trade-war/>.

17. Parfinenko A. (2020) 'Balkansьkiy vimir evropeysьkoyi bezpeki v svitli geostrategiy klyuchovih mizhnarodnih gravtsiv Shodu ta Zahodu' [The Balkan Dimension of European Security in the Light of Geostrategies of the Key International Players of The East and The West], Philosophy and Political Science in the Context of Modern Culture 12(1): 222-232, <https://doi.org/10.15421/352026>. 
18. Parulis-Cook S. (2020) The Southeastern Europe Chinese Tourism Boom, Dragon Trail Interactive, 8 January, <https://dragontrail.com/resources/blog/chinese-tourism-southeasterneurope>.

19. European commentators', European Western Balkans, 30 March,

19. Popović S. (2020) "'Steel friendship" between Serbia and China criticised by $<$ https://europeanwesternbalkans.com/2020/03/30/steel-friendship-between-serbia-and-chinacriticised-by-european-commentators/>.

20. Pavlićević D. (2019) A Power Shift Underway in Europe? China's Relationship with Central and Eastern Europe Under the Belt and Road Initiative. In: Xing L. (ed.) Mapping China's 'One Belt One Road' Initiative, International Political Economy Series, Palgrave Macmillan, Cham, <https://doi.org/10.1007/978-3-319-92201-0_10>.

21. Ponniah K., Marinkovic L. (2019) The night the US bombed a Chinese embassy, BBC News, 18 May, <https://www.bbc.com/news/world-europe-48134881>.

22. Raspor A. Lacmanović D. Popović M. (2018) Chinese tourists in Western Balkan: facts and forecast: Scientific monographs, <https://www.academia.edu/41672489/CHINESE_TOURISTS_IN_WESTERN_BALKAN_FACT S_AND_FORECAST>.

23. Rosenau J. (1979) 'Le toureste et le terroriste ou les deux extremes du continuum international', Etudes Internationales 10(2): 219-252, <https://doi.org/10.7202/700940ar>.

24. Smith O. (2019) 'The unstoppable rise of the Chinese traveller - where are they going and what does it mean for overtourism?', The Telegraph, 2 July, <https://www.telegraph.co.uk/travel/comment/rise-of-the-chinese-tourist/>.

25. Tonchev. P. (2020) China's Soft Power in Southeast Europe, Friedrich-Ebert-Stiftung, <https://www.fes-athens.org/publication/chinas-soft-power-in-southeast-europe/>.

26. Vangeli A. (2019) 'Diffusion of ideas in the era of the Belt and Road: Insights from ChinaCEE think tank cooperation', Asia-Europe Journal 17: 421-436. <https://doi.org/10.1007/s10308019-00564-0>.

27. Balkan Countries Spy Potential in Chinese Tourism (2018), Balkan Insight, 21 September, $<$ https://balkaninsight.com/2018/09/21/china-and-the-balkans-to-boost-cooperation-in-tourism-0920-2018>.

28. Croatia and China Entering "Diamond Period" of Their Relations (2019), Total Croatia News 10 April, <https://www.total-croatia-news.com/politics/35219-croatia-and-china>

29. Ex-Yu-Tour. About the tour (2020), <https://www.flytravel.me/en/tours/ex-yu-tour〉.

30. International Tourism Highlights, 2019 Edition (2019), UNWTO, <http://www.unwto.org>.

31. Tourism ministers and entrepreneurs from China and 17 Central and Eastern European countries agree to strengthen cooperation in the field of tourism (2019), The Ministry of Economics Latvia, <https://www.em.gov.lv/en/news/26972-tourism-ministers-and-entrepreneurs-from-chinaand-17-central-and-eastern-european-countries-agree-to-strengthen-cooperation-in-the-field-oftourism>.

32. Travel \& Tourism: Economic impact (2019), World Travel \& Tourism Council, <https://www.wttc.org/-/media/files/ 2019/world2019.pdf>. reports/economic-impact-research/regions-

33. Varaksina Y. (2018) 'Kitayskie turistyi vernulis v Yuzhnuyu Koreyu' [Chinese tourists return to South Korea], Tourprom, 18 May, <https://www.tourprom.ru/news/39060/>.

34. Gabrielyan G. (2019) 'Kitayskiy poyas primeryayut na Balkanah' [Chinese belt trying on in the Balkans], Novaya gazeta, 30 August, <https://novayagazeta.ru/articles/2019/08/30/81776kitayskiy-poyas-primeryayut-na-balkanah>.

35. Garaeva A. (2018) 'Ukreplenie pozitsiy Kitaya na investitsionnom ryinke Zapadnyih Balkan' [Strengthening China's Position in the Western Balkans Investment Market], Tsentr issledovaniy Stran Vostochnoy Evropyi MGIMO, <https://sinatistis.wordpress.com/2018/02/09/strengtheningchinaspositionintheinvestmentmarketoft hewesternbalkans/>. 
36. Zaklyazminskaya E. O. (2018) 'Ekonomika turizma Kitayskoy Narodnoy Respubliki' [Tourism Economics of the People's Republic of China] (Candidate's thesis). Institut Dalnego Vostoka Rossiyskoy akademii nauk. Moskva, <http://www.ifesras.ru/images/stories/phd/zak/dissertation.pdf>.

37. Miheev V., Shvyidko V. (Eds). (2016) Kitay $i$ Vostochnaya Evropa: zvenya novogo Shelkovogo puti [China and Eastern Europe: Links of the New Silk Road]. Moscow: IMEMO RAN, $120 \mathrm{p}$.

38. Chzhan Bi Yuy (2015) Tendentsii razvitiya turisticheskogo kompleksa Kitaya [Development trends of the tourist complex in China] (Candidate's thesis). Moskovskiy gosudarstvennyiy universitet im. M. V. Lomonosova. Moskva, <https://www.histant.ru/sites/default/files/inafran/BiUi_disser.pdf>.

39. Entina E. G. (2016) Mezhdunarodnyiy kontekst evrointegratsii Zapadnyih Balkan: monografiya [The international context of European integration of the Western Balkans: a monograph]. Moscow: In-t Evropyi RAN, 130 p.

40. Kitay $i$ Serbiya povyisili uroven otnosheniy do vseob'emlyuschego strategicheskogo partnerstva (2016) [China and Serbia upgraded their relationship to a comprehensive strategic partnership], Informatsionnoe agentstvo «Sinhua», <http://russian.news.cn/201606/19/c_135447696.htm>.

41. Kitajskie i serbskie policejskie nachali pervoe sovmestnoe patrulirovanie (2019) [Chinese and Serbian police launched the first joint patrol], Informatsionnoe agentstvo "Sinhua», <http://russian.news.cn/2019-09/19/c_138402555.htm. 